\title{
The Impact of Principal Leadership on The Effectiveness of Learning in Christian Senior High School in Bandung, Indonesia
}

\author{
Junihot M. Simanjuntak \\ Sekolah Tinggi Teologi Kharisma, Bandung, Indonesia \\ joenihot@student.upi.edu
}

\begin{abstract}
The researcher wants to explain the impact of principal leadership on the effectiveness of learning at high school level. The study is aimed at finding principal leadership model as an ideal example in managing school as an educational institution to bring effective learning as an output. The results of the discussion show that the principal's leadership has a significant positive effect on teacher competence to realize the effectiveness of learning. The conclusion from this discussion that the effectiveness of learning can run well can be done by applying the leadership of the principal and teacher competence. The Principal has strong influence because he leads with love, gives positive impact on school even outside world. He has become catalyst agent who brings others to a purpose, by making himself as not only a creator of culture but also the one who sustains it especially inside school environment. The better the leadership of the principal is, the better the learning effectiveness at the school is.
\end{abstract}

Keywords: Leadership, Principal, Effectiveness of Learning

\section{Article Info}

Received date: 1 Februari 2021

Revised date: 21 Juni 2021

Accepted date: 21 Juni 2021

\section{INTRODUCTION}

Principal leadership is in need in connection with learning effectiveness. Regarding the tasks of principal as an administrator, should have an ability to manage curriculum administration, student administration, human resource administration, infrastructure administration, and archive administration (Kemendikbud, 2017). However, the reality is in contrary, a principal fail in doing his task as an administrator (Maya, 2012). Soekarno states that in relation with the failure of principal in doing administration tasks, in which organization structure pattern and working data that have been established are not carried out, and structural organization doesn't work (1986). But, based on field study findings, Maya explains that principal doesn't make any new innovation within Scholl system. It gives impacts of the emerging of unexpected situation such as low degree of pedagogic, inefficient school management, slow development of institution, etc (Maya, 2012).

Some research has suggested that "schools bring little influence to bear upon a child's achievement that is independent of his background and general social context" (Coleman, 1968, p. 325; see also . Other evidence suggests that factors like class size (Glass et al, 1982; Mosteller, 1995), teacher qualifications, school size (Haller, E. J.; Monk, D. H.; \& Tien, 1993), and other school variables may play an important role in what students learn. 
In the United States, research by Weber (Schneider, 1971), Austin (1978), Lazotte and Brookeover (1979), Edmonds and Fredericson (1979), (The Phi Delta Kappa, 1980), in general: there is strong leadership, students and teachers have hope high (high expectation), conducive school environment, principal as instructional leader, student achievement progress often monitored, and presence of parental involvement support.

Regarding the task of principal as an educator who gives counsel to school citizen, he should actively encourage all teachers, and make interesting teaching model such as team teaching, moving class, acceleration class for above average students. But in reality it is found in contrast, a principal as a school leader doesn't care about society social network. This is due to a more oriented leader on the task, that the subordinates are forced to work hard so that there is distance from the subordinates (Agustina, 2018). After school hours, principal as well as teacher does not care about what their students are doing. In other words, school is only a place for students to spend time from morning until noon, and then after that they are free to go wherever they like. In the other case, it is found that principal doesn't provide creative room for teachers and students to develop their potential for the sake of school progress (1986). From the explanation above, it is concluded that there is a strong correlation between the role and responsibility of principal in school activity as a leader and the effectiveness of study, and if it is neglected, the serious impact of the neglect of pedagogic service and quality will happen.

Furthermore, below will be explained about the literature review, relating to the relationship between principal leadership on the effectiveness of learning

\section{Principal Leadership}

In short, principal can be defined as functional teacher who is given task to lead a school where learning and teaching process are carried out, or a place where interaction between teacher who gives teaching and student who receive teaching happens. Leadership in this sense is an ability to move resources both internal and external to active school goals optimally. Another definition of the principal is a person who has the ability to influence members of the organization (educational human resources) to carry out activities for the purpose of active school education. The school principal is a leader who carries out his role in leading the school as an educational institution, the principal acts as an education leader.

According to the Rule of Minster of National Educational No. 12 year 2007 about competence standard of supervisor, that principal as a supervisor should have competence standards: (a) guiding teachers in making syllabus for each subject; (b) guiding teachers in preparing Teaching Process Plan; (c) guiding teachers in carrying out learning/mentoring activity; (d) guiding teachers in managing, taking care of, developing and using educational tools and learning facilities for each subject; (e) motivating teachers to make the most of information technology in learning each subject (Juni Priansa, 2014).

The leadership of principal will go well and will reach its goal when he has an ability to develop the achievement of his followers. It can be seen in the thought of Munir Abdullah (2010) who says that the effective leadership of a principal will be in its context, the ability to give vision, create a big picture, set clear consensus goal, monitor and make analysis of achievement and be able to develop the achievements of his followers, by giving guidance and direction, training and coaching, and giving feedback.

\section{Effectiveness of Learning}

To measure the effectiveness of an organization can be seen from the extent to which the organization has met the stated goals 
and objectives and how well it is performing in the process (Yankey, J.A., \& McClellan, 2003).

The effectiveness of learning can be measured from how an educational institution is able to produce useful and purposeful learning for students through correct learning (Yusuf Hadi Miarso, 2004). As for the characteristics of effective learning activities, namely: (a) systemic, which is carried out through the process of planning, developing, executing, assessing, and perfecting; (b) being sensitive to the need for the task of learning and the need of learner;(c) the clarity of goal so that the effort can be made to achieve it; and (d) based on the ability and the strength of learners, teachers, society and government (Ahim Surachim, 2016).

Wotruba and Wright as quoted by Hamzah and Nurdin (2004) identify five indicators that can show the success of effective learning: (1) effective organization of source materials; (2) effective communication; (3) enthusiasm and understanding of effective learning materials; (4) positive attitude towards learners; (5) effective assessment.

At least five reviews of empirical research on the direct and indirect effects of leadership on student outcomes have recently appeared (Bell, L., Bolam, R. and Cubillo, 2002; Leithwood, K. , Day, C. , Sammons, P. , Harris, A. , \& Hopkins, 2006; Leithwood, Louis Seashore, Anderson, 2004; Marzano, R.J., Waters, T. , \& McNulty, 2005)

The activity of principal leadership is shown in managing all organization system in school, beginning from planning to evaluation. With this in mind, a principal must have strong vision of school learning, have high hope for the achievement of learners, make program and monitor teacher's activities and learning in class, encourage to make the most of time efficiently, use different source of learning, supervising the development of learners individually as well as in groups, evaluate and make continual improvement.
Between learning, teaching, and leadership have an inseparable relationship in the effort to achieve the goals of education and learning. Suggests, learning, teaching and leading are intricately intertwined. To learn is to understand the essence of teaching; to teach is to understand the essence of leading. This relationship is a vital understanding that can reduce the complexity of leading to the simple truth human learning propels each of these concepts (Lambert, 2002).

Based on the explanation above, when a principal does his job and carries out his responsibility well, the effectiveness of learning at school can be achieved. Because principal gives positives influence to his men and learner, so that they have power to get achievement.

The empirical results as described above reinforce the picture that various problems of professionalism of teachers in Christian religious education subjects that are built from research work and publication of scientific papers are general problems that must be given solutions. It is necessary to develop and manage teacher resources in a systematic, systemic, integrated and quality manner (Simanjuntak, Junihot M., Udin Syaefuddin Sa'Ud, Aan Komariah, 2019a). This problem is related to policy and personnel management such as planning, recruitment, appointment and coaching, development management, courage and the ability to provide guidance to those in accordance with modern science and technology developments (Sanusi, 1987). If this is allowed to drag on, it will be detrimental to improving the quality of teachers and the quality of education. Things that need to be considered in the improvement, namely: continuous improvement, determining quality standards, culture changes, and organizational changes (Simanjuntak, Junihot M., Udin Syaefuddin Sa'Ud, Aan Komariah, 2019b). 


\section{RESEARCH METHOD}

This type of research is qualitative research using a case study approach. Qualitative research using a case study approach was chosen because it was considered capable of answering research questions about phenomena, events, and their relationships used to understand, analyze behavior and relate it to how the principal's leadership influences the effectiveness of learning at the senior high school level.

Methods for analyzing in accordance with the objectives are quantitative approaches and descriptive methods. There are three stages carried out, namely (1) principal leadership on the effectiveness of learning carried out by teachers in schools, (2) school climate on the effectiveness of learning carried out by teachers in schools, and (3) principal leadership and school climate. together on the effectiveness of learning carried out by teachers in schools The relationship between variables is presented in the following figure.

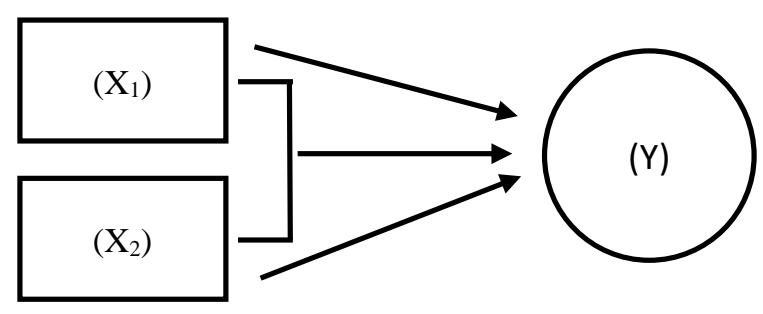

Information:

Picture 1. Research Model Design

$\mathrm{X} 1=$ Principal leadership

$\mathrm{X} 2=$ Organizational climate

$\mathrm{Y}=$ The effectiveness of teacher learning in schools

This research was conducted in three Christian high schools in the city of Bandung. The research time is from January to June 2017.

The subjects of this study were the principal, teachers / employees, and students.
The total population is 231. Determination of the subject in this study was carried out using proportional random sampling technique.

The research was conducted by observing the activities of the principal. In addition, observations were made regarding school habits, rules and symbols. Researchers interact directly with research subjects.

Primary data is data obtained directly from informants in the form of words and actions. Primary data in this study include respondents' opinions regarding leadership behavior and learning effectiveness that have developed in three Christian high schools in Bandung. Secondary data is data obtained from data collection techniques that support primary data. In this study, secondary data includes source data from archives, official documents, literature and other documents related to research problems as well as official documents from the three schools.

The data collection techniques used were observation, interview, and documentation. The data collection instruments used were observation guidelines, interview guidelines and documentation guidelines. The validity of the research data used was source triangulation and method triangulation.

The analysis of this research uses the interactive analysis model of Miles and Huberman (Silalahi, 2012) which consists of four steps, namely collection, reduction, display, and conclusion.

\section{RESULT AND DISCUSSION \\ Result}

The results of the study present the results of statistical calculations, which can be represented in tabular form, as presented in Table 2. 
Table 2. Calculation Results

\begin{tabular}{|c|c|c|c|c|c|}
\hline Main Hypotheuis & $\begin{array}{c}\text { PathCoefinet } \\
\text { ent }\end{array}$ & $F_{\text {trat }}$ & Funt & Determinant: & $\begin{array}{l}\text { Meaning of } \\
\text { Relarionshios }\end{array}$ \\
\hline 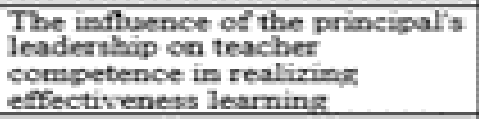 & 0,3453 & 3,901961 & 1,506003 & 0,5922 & significant: \\
\hline Sub Hypothesis & $\begin{array}{c}\text { FathCoeffici } \\
\text { ent }\end{array}$ & $F_{\text {anut }}$ & Funh & Determinants & $\begin{array}{l}\text { Meaming of } \\
\text { Relationships }\end{array}$ \\
\hline $\begin{array}{l}\text { The influence of the principal's } \\
\text { leaderthip on teacher } \\
\text { somprtmos }\end{array}$ & 0,8977 & 16.5557 & 1.9977 & 0,8059 & gigeifienst \\
\hline $\begin{array}{l}\text { Leadership infoence prineipal } \\
\text { on the effectivenesel of lesuning }\end{array}$ & 0,3453 & 2,6943 & 1,9977 & 0,1193 & significant \\
\hline $\begin{array}{l}\text { Efect of tescher competence } \\
\text { on efectiveness learning }\end{array}$ & 0,5601 & 4,5039 & 1.9977 & 0,5003 & significnst \\
\hline
\end{tabular}

To test the hypothesis obtained (1) there is a positive and significant influence of principal leadership on the effectiveness of learning held by teachers in schools which is stated by the regression coefficient $\mathrm{Y}=106.275$ $+0.308 \mathrm{X} 1$, the strength of the correlation is 0.525 with a contribution of 0.276 or $27.6 \%$, whereas the remaining $100 \%-27.6 \%=72$, $4.0 \%$ is still influenced by factors or other causes outside the variables studied. (2) there is a positive and significant effect of school climate on the effectiveness of learning held by teachers in schools which is stated by the regression coefficient $\mathrm{Y}=94.583+0.402 \mathrm{X} 2$, the strength of the correlation is 0.411 with a contribution of 0.169 or $16.9 \%$, while the rest is $100 \%-16.9 \%=83.1 \%$ are still influenced by other factors or causes outside the variables studied, and (3) there is a positive and significant influence of principal leadership and school climate together on effectiveness learning organized by teachers in schools is stated by the regression coefficient $\mathrm{Y}=83.543$ $+0.250 \mathrm{X} 1+0.190 \mathrm{X} 2$, the strength of the correlation is 0.506 with a contribution of 0.304 or $30.4 \%$. while the remaining $100 \%-30.4 \%=$ $69.6 \%$ is still influenced by other factors or causes outside the variables studied.

From the results of data analysis. From the results of the respondents' responses to the dimensions of school objectives, the indicator of school objectives was clearly stated to have the highest score of 4.86 , but it was only slightly adrift with other indicators. This assumes that some schools have been able to set their own school goals by exploring strengths, weaknesses, threats and opportunities (SWOT analysis) that are in accordance with the conditions of their respective schools, and then disseminate them to school members.

From the dimension with the lowest score of 3.67, namely the expectations of teachers and staff on indicators emphasizing academic results compared to other indicator scores. This must be considered by a school principal, because there are still many school principals who lack emphasis on academic results, so the school principal should always try to facilitate all students to be able to achieve high so that every year the average US and UAS scores increase and always trying to provide maximum educational services. From the findings in the field, there are still many schools that have incomplete facilities to support efforts to improve student achievement. Thus, it is concluded that in general the effectiveness of learning held by teachers at Christian Senior High Schools in Bandung is in the very high category, but still needs to be improved and improved.

\section{Discussion}

The principal as the leader of an educational institution must be able to carry out leadership management well. The success of the principal's leadership in its activities is influenced by factors that can support the success of a leadership, therefore a goal will be achieved if there is harmony in good relationships or interactions between superiors and subordinates, in addition to being 
influenced by the background of the leader, such as self-motivation for achievement, maturity and flexibility in social relations with human relationship attitudes.

The community trusts, recognizes and leaves it up to teachers to educate young shoots and help develop their potential in a professional manner. This trust, belief, and acceptance is the substance of public recognition of the teaching profession. The implication of this recognition requires that teachers must have adequate competence and quality. Not only at the normative level, but also able to develop competencies, both personal, professional and social competences in the veil of actualization of educational policies. This is because teachers are a determinant of the success of education through their performance at the institutional and experiential levels, so that efforts to improve the quality of education must start from the aspect of "teachers" and other education personnel concerning the quality of their professionalism and welfare in a professional educational management. Although it is realized that in addition to the role of teachers and schools, the environment will also have an impact on the success rate of education (Ramdhani, 2014).

The influence of the principal's leadership on teacher competence in realizing learning effectiveness.

The formulation of the main hypothesis proposed in this study is "there is an influence of the principal's leadership on teacher competence to realize the effectiveness of learning in Christian Senior High Schools in Bandung City.

To answer the proposed hypothesis, testing is carried out using path analysis testing. Based on the results of data processing, the R2 value was 0.8922 . . To find out more about the influence of the principal's leadership variable on teacher competence to realize the effectiveness of learning in Christian Senior High Schools in 16
Bandung, a test was conducted by comparing the value of Fcount with Ftable. Based on the calculation results, the Fcount value of 3.901961 is greater than the Ftable value of 1.506093. From this value, a statistical conclusion can be drawn that $\mathrm{HO}$ is rejected, meaning that there is an influence of the principal's leadership on teacher competence to realize the effectiveness of learning in Christian Senior High Schools in Bandung.

The significance of the value of the test results above, is also supported by the value of the Coefficient of Determination R2 of 0.8922 which also shows the size of the principal's contribution to teacher competence to realize learning effectiveness, which is $89.22 \%$, while the rest is 0.1078 or $10,78 \%$ is influenced by other variables which are not observed in this study.

The test results can be explained that the principal's leadership has a significant positive effect on teacher competence to realize the effectiveness of learning. This is relevant to what was stated by Wahyudi (2013) explaining that the principal helps carry out activities that are technical in nature to support smooth school programs where part of the tasks have been delegated to teachers or school administration officers.

Competencies needed by school principals include skills in leadership, skills in human relationships, skills in group process, skills in personal administration and skills in evaluation. Skills in leadership (skills in leadership), namely the principal can influence and direct subordinates (teachers) to achieve school goals through activities to increase member participation in preparing school programs, create a conducive work climate, delegate some responsibilities and include teachers -teacher in making decisions and encouraging creativity of members and provide opportunities for teachers to perform. 
Furthermore, there are other factors that influence the principal's leadership on teacher competence to realize learning effectiveness, namely: that the principal's leadership has a significant positive effect on teacher competence in realizing learning effectiveness. This is relevant to what was stated by Mulyasa (Mulyasa, 2013), that there is a close relationship between the quality of school principals and various aspects of school life such as school discipline, school cultural climate, and decreased mischievous behavior of students. The principal is responsible for the implementation of educational activities, school administration, coaching other educational personnel and the utilization and maintenance of facilities and infrastructure. This means that the good and bad of the principal's leadership will greatly affect all elements in the educational environment, one of which is teacher competence and learning outcomes. One of the important roles of the principal is to formulate a consensus as a collective agreement in achieving certain goals. Ramdhani \& Suryadi (2005) defines consensus as an agreement between human perceptions in a win-win solution approach.

\section{The influence of the principal's leadership} on teacher competence

The formulation of the hypothesis proposed is: "there is an influence of the principal's leadership on teacher competence". To answer the sub-hypothesis, a test was carried out using path analysis. Based on the results of data processing, it is known that the path coefficient value $\mathrm{X} \rightarrow \mathrm{Y}$ (Pyx) is 0.8977. To find out more about the influence of the principal's leadership variable on teacher competence, testing was carried out by looking at the comparison between $t_{\text {count }}$ and $t_{\text {table. }}$ Based on the test, the $\mathrm{t}_{\text {count }}$ value is obtained, namely $\mathrm{t}_{\text {count }}=$ 16.5557 and $t_{\text {table }}$ value $=1.9977$. Furthermore, to see the significance of this effect is done by comparing the value of $t$ count with $t$ table, where the results show that the value of $t$ is greater than $t_{\text {table, namely: }}$ $\mathrm{t}_{\text {count }}=16.5557>\mathrm{t}_{\text {table }}=1.9977$, meaning that $\mathrm{HO}$ is rejected or it can be stated that there is a significant influence. the significance of the principal's leadership variable on teacher competence. Furthermore, to see the significance of this effect is done by comparing the value of $t_{\text {count }}$ with $t_{\text {table, }}$, where the results show that the value of $t$ is greater than $\mathrm{t}_{\text {table, }}$, namely: $\mathrm{t}_{\text {count }}=16.5557>\mathrm{t}_{\text {table }}=$ 1.9977, meaning that $\mathrm{HO}$ is rejected or it can be stated that there is a significant effect of the principal's leadership variable on teacher competence.

The value of the coefficient of determination shows that the influence of the principal's leadership variable on teacher competence is only $80.59 \%$, while the remaining $19.41 \%$ is influenced by other variables outside the teacher competency variable which are not included in the model.

This can be related, because the principal continues to experience developments and changes in accordance with the records and perceptions of individuals who continue to experience changes. Mulyasa (Mulyasa, 2013) argues that the functions of school principals are as follows: 1) The principal as an educator, through: increasing job qualifications, improving coaching, compiling work programs, and increasing academic achievement; b) The principal as a manager, including: empowering cooperation, utilizing school resources, improving the profession persuasively, and encouraging active activities; c) The principal as administrator, including: student administration, personnel administration, financial administration; d) The principal as a supervisor, including: controlling, compiling and implementing a supervision program, carrying out group discussions, and carrying out class visits; e) 
The principal as a leader, including: personality, communication skills, understanding and developing a vision and mission; f) Principals as innovators, include: constructive, creative, delegative, pragmatic, and adaptable; g) The principal as a motivator, including: setting the environment, setting the work atmosphere, and renewal.

Increasing teacher competence can be done with the principal's initiative to build teacher capacity. The use of information technology as an alternative for knowledge management in schools can create a good learning climate and culture for teachers to increase their capacity (Ainissyifa, 2012).

Technology is a device that makes human work easier (Bustomi, Y., Ramdhani, M. A., \& Cahyana, 2012; Tsabit, Ramdhani, \& Cahyana, 2012; Slamet, Rahman, Ramdhani, \& Darmalaksana, 2016). In the context of increasing the effectiveness of learning, it is necessary to take the initiative of the principal, so that teachers have the capacity and capability to use current learning technologies that are able to increase the effectiveness of learning in schools.

Principals can increase teacher capacity through strengthening school culture. In principle, school culture is an organizational culture that is expected to be able to move organizational members to be committed to achieving organizational goals (Ramdhani, A., Ramdhani, M. A., \& Ainisyifa, 2017), so that teachers have a commitment to increase their own capacity and are expected to increase the effectiveness of the learning process in the classroom.

\section{The influence of the principal's leadership on the effectiveness of learning}

The formulation of the hypothesis proposed is: "there is an effect of the competence of teachers who have learning". To answer the sub-hypothesis, the test is carried out using path analysis. Based on the 18 results of data processing, it is known that the path coefficient value $\mathrm{Y} \rightarrow \mathrm{Z}$ (Pzy) is 0.5691 .

To find out more about the influence of teacher competency variables on the effectiveness of learning, testing was carried out, namely by looking at the comparison between $\mathrm{t}$ and $\mathrm{t}$ table. Based on the test, the $\mathrm{t}-$ value value is 4.8039 and the t-table value is 1.9977. Furthermore, to see the significance of this effect is done by comparing the value of $t_{\text {count }}$ with $t_{\text {table, }}$ where the results of the study show that $\mathrm{t}_{\text {count }}$ is $4.8039>\mathrm{t}_{\text {table }} 1.9977$, meaning that $\mathrm{HO}$ is rejected or it can be stated that there is a significant influence of teacher competency variables on the effectiveness of learning in Christian Senior High Schools in Bandung.

The value of the determinance coefficient indicates that the influence of the teacher competency variable on the effectiveness of learning is $50.03 \%$, while the remaining $49.97 \%$ is influenced by other variables which are not observed in this study. Thus, this condition shows that teacher competence has a significant positive effect on the effectiveness of learning.

As for other factors that affect teacher competence on the effectiveness of learning, it is suspected that this is in line with what Slameto (2013: 64) said, saying that school factors that influence learning include teaching methods, curriculum, teacherstudent relations, student-student relations. , school discipline, lessons and standard school time, the state of the building, learning methods and homework (Ramdhani, M. A., \& Wulan, 2012), and Ramdhani \& Muhammadiyah (2015) state that the effectiveness of learning is influenced by the use of learning technology / media by teachers.

\section{The influence of teacher competence on the effectiveness of learning}

The formulation of the hypothesis proposed "there is an influence of the principal's leadership on the effectiveness of learning". To 
answer the proposed hypothesis, testing was carried out, namely by using path analysis testing. Based on the test results, the path coefficient (Pzx) is 0.3453 .

To find out more about the influence of the principal's leadership on the effectiveness of learning, testing was carried out, namely by looking at the comparison between $\mathrm{t}$ and $\mathrm{t}$ table. Based on the test results, it is obtained that the value of $t$ is greater than $\mathrm{t}$ table, namely $\mathrm{t}_{\text {count }}=$ $2.6943>\mathrm{t}_{\text {table }}=1.9977$. From these results, it is obtained that Ho's decision is rejected, so that the principal leadership variable affects the effectiveness of learning.

From the test results, it is known that the principal's leadership has a significant influence on the effectiveness of learning. The amount of direct influence of the principal's leadership on the effectiveness of learning is 0.119 or $11.93 \%$. While the influence of the principal's leadership on the effectiveness of learning through teacher competence is 0.1764 or $17.64 \%$ so that the direct and indirect influence of leadership on the effectiveness of learning is 0.2957 or $29.57 \%$ while the remaining $70.43 \%$ is influenced by other variables. outside $\mathrm{k}$ which is not included in this model.

From the results of teacher research conducted at Christian Senior High School in Bandung, it shows that the leadership and motivation of the principal have a significant contribution together to teacher performance. So it can be said that the better the principal's leadership and motivation, the better the teacher's performance. This study is in line with research (Barnes, 2013), that principal leadership and motivation have a significant relationship, have the same respondents, namely teachers, the data collection method uses a questionnaire. However, this study has differences with the research (Barnes, 2013), the data analysis uses product moment correlation.

\section{CONCLUTIONS AND SUGGESTION}

The results showed that the leadership of the principal in Christian Senior High Schools in Bandung had a simultaneous and positive effect on teacher competence in realizing learning. Furthermore, to realize the success of good learning, it can be done by increasing the implementation of school principal leadership and good teacher competence.

It can be concluded that the principal's leadership and motivation have a relationship and contribution to teacher performance. Leadership to influence, coordinate, organize so that a job can run regularly and in accordance with what is desired. Motivation too, is very necessary in a performance in an organization. Good leadership without good motivation will also not work well to achieve a common goal. It's just that the contribution of motivation is much greater than leadership. A leadership is obtained from someone outside the person being led, while motivation is an encouragement that can be obtained from within humans or from within humans.

From the results of teacher research conducted at Christian Senior High School in Bandung, it shows that the leadership and motivation of the principal have a significant contribution together to teacher performance. So it can be said that the better the principal's leadership and motivation, the better the teacher's performance. This study is in line with research (Barnes, 2013), that principal leadership and motivation have a significant relationship, have the same respondents, namely teachers, the data collection method uses a questionnaire. However, this study has differences with the research (Barnes, 2013), the data analysis uses product moment correlation.

The suggestions are given to the institution where the research has been done, 
that is the principals of Christian Senior High Schools in Bandung. The suggestions are: (1) The Principals need to understand theoretical thinking before making steps in schools so that the maximum relationship between principal and the teachers can be built to achieve learning effectiveness. Principals are hoped to rate and constantly renew their knowledge about principal leadership theory. They must have good personality and integrity and can built harmonious relationship between school and outside world, and they have to upgrade themselves by entering post graduate programmed on education an principal leadership; (2) All teacher and staff members must maintain the values of the school, keep the harmony and cooperation between principal and teachers, between teachers and teachers, and between teachers and students to achieve school goal; (3) Parents have important role in helping to control students when they are in the society so that they can follow all learning process provided by schools.

\section{REFERENCES}

Agustina, P. (2018). Characteristics Of Leadership Behavior Of Schools And Culture School In Basic School. Jurnal Pendidikan Karakter, 8(2).

Ainissyifa, H. (2012). The Influence of Organizational Culture toward Knowledge Management Implementation on Secondary Education Institution. International Journal of Research in Management, 2(3), 134-139.

Barnes, J. G. (2013). Secerets of Customer Relationship Management. Andi.

Bell, L., Bolam, R. and Cubillo, L. (2002). A systematic review of the impact of school leadership and management on student outcomes. In Research Evidence in Education Library. EPPI-Centre,
Social Science Research Unit, Institute of Education.

Bustomi, Y., Ramdhani, M. A., \& Cahyana, R. (2012). Geographical Information System Design and Distribution of Information Technology Research Sites in Garut City. Jurnal Algoritma, 9(1), $1-7$.

Coleman, J. . (1968). The concept of equality of educational opportunity. Harvard Educational Review, 38, 7-22.

Glass et al. (1982). Cognitive assessment of social anxiety: Development and validation of a self-statement questionnaire. Cognitive Therapy and Research, 6, 37-55.

Haller, E. J.; Monk, D. H.; \& Tien, L. T. (1993). Small schools and higher-order thinking skills. Journal of Research in Rural Education, 9, 66-73.

Juni Priansa, D. \& R. S. (2014). Manajemen Supervisi \& Kepemimpinan Kepala Sekolah. Alfabeta.

Kemendikbud. (2017). Modul Pengelolaan Administrasi Sekolah. Direktorat Jenderal Guru Dan Tenaga Kependidikan.

Lambert, L. (2002). A Framework for Shared Leadership. Educational Leadership.

Leithwood, K. , Day, C. , Sammons, P. , Harris, A. , \& Hopkins, D. (2006). Seven strong claims about successful school leadership. National College of School Leadership.

Leithwood, Louis Seashore, Anderson, \& W. (2004). Investigating the links to improved student learning: Final report of research findings to the Wallace Foundation.

Marzano, R.J., Waters, T. , \& McNulty, B. (2005). School leadership that works: 
From research to results. ASCD and McREL.

Maya, H. (2012). Kesalahan-Kesalah umum Kepala Sekolah Dalam Mengelola Pendidikan. Buku Biru.

Mosteller, F. (1995). The Tennessee study of class size in the early school grades. The Future of Children, 5(2), 113-127.

Mulyasa, E. (2013). Menjadi Kepala Sekolah Profesional. PT Remaja Rosdakarya.

Ramdhani, A., Ramdhani, M. A., \& Ainisyifa, H. (2017). Conceptual Framework of Corporate Culture Influenced on Employees Commitment to Organization. International Business Management, 11(3), 826-803.

Ramdhani, M. A., \& Wulan, E. R. (2012). The Analysis of Determinant Factors in Software Design for Computer Assisted Instruction. International Journal of Scientific \& Technology Research, 1(8), 69-73.

Ramdhani, M. A. (2014). Educational Environment in the Implementation of Character Education. Jurnal Pendidikan Universitas Garut, 8(1), 27-36.
Schneider, L. (1971). Max Weber: Wisdom and Science in Sociology. The Sociological Quaterly, 12.

Silalahi, U. (2012). Metode Penelitian Sosial. Refika Aditama.

Simanjuntak, Junihot M., Udin Syaefuddin Sa'Ud, Aan Komariah, A. S. (2019a). Continuing Professional Development Of Lecturer's Research Training Model Based On Research Product. Opción, 35(89), 564-581.

Simanjuntak, Junihot M., Udin Syaefuddin Sa'Ud, Aan Komariah, A. S. (2019b). Model Pelatihan Berbasis Produk Untuk Meningkatkan Kinerja Penelitian dan Publikasi Karya Ilmiah. Jurnal Jaffray, 17(1), 107-122.

The Phi Delta Kappa. (1980). What is a title history? Phi Delta Kappa International, 62(4).

Yankey, J.A., \& McClellan, A. (2003). The nonprofit board's role in planning evaluation Book Seven of the BoardSource Governance Series. Quoted in "Nonprofit Organizational Effectiveness". International Journal of Business and Behavioral Sciences. 